\title{
Microleakage of Indirect Composite Resin Luted With Different Adhesive Cements
}

\author{
Farklı Rezin Simanlar ile Simante Edilen Indirekt Kompozit \\ Restorasyonların Mikrosızıntı Miktarının Değerlendirilmesi
}

\author{
Gamze PAKEN $^{1}, \underline{\text { Mine Dündar Cömlekoğlú }}{ }^{2}$, Mehmet Sonugelen $^{2}, \underline{\text { L. S Șebnem Türkün }}^{3}$ \\ ${ }^{1}$ Department of Prosthodontics, Usak University, School of Dentistry, Usak, Turkey \\ ${ }^{2}$ Department of Prosthodontics, Ege University, School of Dentistry, Izmir, Turkey \\ ${ }^{3}$ Department of Restorative Dentistry, Faculty of Dentistry, Ege University, Izmir, Turkiye
}

Atıf/Citation: Paken, G., Çömlekoğlu Dündar, M., Sonugelen, M., Türkün, L.Ş., (2021). Microleakage of Indirect Composite Resin Luted with Different Adhesive Cements. Ege Üniversitesi Diş Hekimliği Fakültesi Dergisi, 42(2), 99-105.

\begin{abstract}
Objective: To evaluate the influence of different adhesive cements on the microleakage of proximal surfaces in class II indirect composite resin restorations.

Material and methods: Twenty-four human extracted caries-free third molars were selected. Standard class II cavities were prepared on the mesial and distal surfaces with margins located above the cementoenamel junction (CEJ). Cavities were standardized by fixing the handpiece in a parallelometer during preparation. Treatment groups were divided into 4 cements: GCem LinkAce (GCm) (GC, Japan), Panavia F 2.0 (P) (Kuraray, Japan), RelyX U200 (Rx) (3M ESPE, USA), Superbond C\&B (SB) (SunMedical, Japan) and control (V) (Variolink II, Ivoclar Vivadent, Schaan, Liechtenstein). In each tooth, the mesial cavity was set as the experimental and the distal as a control. Restorations were fabricated with an indirect composite resin (Gradia; GC, Japan) and luted into cavities. Specimens were thermocycled $\left(5-55 C^{\circ}, 5000\right.$ cycles) and immersed in 50\% silver nitrate solution for 24 hours. The teeth were sectioned mesiodistally and evaluated for microleakage using digital image analysis (24x; Leica optical microscope, Germany). The ordinal scale used was: 0-4 ( $0=$ no microleakage and $4=$ dye penetration along axial wall). Mean values for each group were recorded and statistically analyzed using Wilcoxon Signed Ranks Test. (alpha=0,05)

Results: There were no significant differences among occlusal microleakage of all groups (GCm:0; $P: 0,17 \pm .0,4 ; R x: 0$ and $S B: 0,17 \pm .0,4)(P>0,05)$. The least microleakage $(\mu m \pm S D)$ was recorded for $\mathrm{GCm}$ and $R x$ self-adhesive cements for occlusal $(0.00$; $0,00)$ and gingival $(0,83 \pm 0,4 ; 0,50 \pm 0,5)$ parts, respectively. The highest microleakage was noted with $S B$ and $P$ at the gingival parts $(2,0 \pm 1,4 ; 1,5 \pm 0,84)$, respectively and the difference was significant compared to the other groups $(P<0,05)$.

Conclusions: Tested self-adhesive dual-curing resin cements exhibited simulated long-term microleakage stability while self-curing resin cement yielded highest microleakage.
\end{abstract}

Keywords: Indirect composite, microleakage, resin cement

öz

Amaç: Bu çalışmanın amacı, Sınıf II indirekt kompozit resin restorasyonlarda, farklı adeziv simanların proksimal yüzeylerdeki mikrosızıntıya etkisinin değerlendirilmesidir.

Gereç ve yöntem: Bu çalışmaya 24 adet çekilmiş, çürüksüz üçüncü molar diş dahil edildi. Standart Sınıf Il kaviteler dişlerin hem distal hem de mesial yüzeylerinde ve mine-sement birlessiminden yukarıda olacak şekilde hazırlandı. Calışma grupları 4 siman grubuna ayrıldı: GCem LinkAce (GCm) (GC, Japonya), Panavia F 2.0 (P) (Kuraray, Japonya), RelyX U200 (Rx) (3M ESPE, ABD), Superbond C\&B (SB) (SunMedical, Japonya) ve kontrol (V) (Variolink II, Ivoclar Vivadent, Schaan, Liechtenstein). Her bir diş için mesial kavite çalışma grubu olacak şekilde ve distal kavite ise kontrol grubu olacak şekilde ayarlandı. Restorasyonlar indirekt kompozit materyalinden (Gradia; GC, Japonya) elde edildi ve kavitelere yapıştırıldı. Örneklere termosiklus uygulandı (5-55C ${ }^{\circ}, 5000$ döngü) ve sonrasında örnekler 24 saat boyunca \%50 gümüs nitrat solüsyonunda bekletildi. Dişlerden mesio-distal olarak kesit alındı ve mikrosızıntı miktarları dijital görüntüleme yöntemi ile (24x; Leica optik mikroskop, Almanya) değerlendirildi. Kullanılan sıralı ölçek: 0$4(0=$ mikro sızıntı yok ve $4=$ aksiyel duvar boyunca boya penetrasyonu). Her grup için ortalama değerler kaydedilmiş ve bu değerler Wilcoxon Signed Ranks testi kullanılarak istatistiksel olarak analiz edilmiştir. (alpha=0,05)

Bulgular: Tüm grupların oklüzal mikrosızıntı değerleri arasında anlamlı bir fark yoktur (GCm: 0; P: 0,17 $\pm .0,4 ; R x: 0$ ve SB: $0,17 \pm$ $.0,4)(P>0,05)$. En az mikrosızıntı değerleri $(\mu m \pm S D)$ sırasılyla oklüzal $(0.00 ; 0,00)$ ve gingival $(0,83 \pm 0,4 ; 0,50 \pm 0,5)$ ksımlar için GCm ve Rx kendinden adezivli simanlar için kaydedildi. En yüksek mikrosızıntı SB ve $P$ ile gingival kısımlarda $(2,0 \pm 1,4 ; 1,5 \pm 0,84)$ kaydedildi ve fark diğer gruplara göre anlamlıdır. $(P<0,05)$.

Sonuç: Test edilen kendinden adezivli dual-cure rezin simanlar uzun süreli mikrosızıntı stabilitesi sergilerken, self-cure rezin simanlar en yüksek mikrosızıntı değerleri göstermiştir.

Anahtar Kelimeler: Indirekt kompozit, mikrosızıntı, rezin siman

Sorumlu yazar/Corresponding author*: gamzepaken@gmail.com

Başvuru Tarihi/Received Date: 10.06.2020

KabulTarihi/Accepted Date: 03.09.2020 


\section{INTRODUCTION}

The adequacy of the adhesion among the restorative material and cavity is essential for the long-term success of the restorations. The leading disadvantage of the resin material is the marginal leakage after the polymerization shrinkage occurs. The shrinkage occurring in the composite resin during polymerization can bring out contraction forces and this negatively affects bonding amongst the dental tissue and composite resin. ${ }^{1}$ In addition, polymerization shrinkage causes clinical problems such as microleakage, post-operative sensitivity, recurrent caries and negative pulpal pressure. ${ }^{2}$

Particularly in the Class II cervical margins, microleakage is the most frightening situations caused by resin polymerization shrinkage. ${ }^{1}$ The leakage of cariogenic bacteria throughout the cavity walls can result in secondary caries, pulp inflammation and pulp necrosis. ${ }^{3}$ The microleakage symptoms such as discoloration in marginal area, immediate and continuing postoperative sensitivity have been identified as the primary causes of composite resin restoration replacement. $^{2}$

In dentistry, the acid etching of the enamel surface applied before the resin bond to the tooth structure is a clinically successful administration. Nevertheless, due to complexity of dentin, adhesion to dentin is not safe and clear compared to enamel. ${ }^{4}$ It is difficult to determine the finishing line of cavity preparation in dentin, especially if caries occurs on the deep dentine of the posterior tooth andt his leads to poor adhesion in Class II composite resin restorations.

Miscellaneous composite resin techniques have been used such as direct and indirect composite resin systems. When applying direct composite resin technique, clinicians may have difficulty in giving the anatomical form, proximal contour and obtaining proximal contact To overcome these problems and attain better marginal adaptation, indirect composite resin systems have been developed. Thus, minimizing polymerization shrinkage is made possible via this technique. ${ }^{1}$ However, the indirect restoration bonding procedure is still challenging due to the increasing number of adhesive surfaces.

For indirect restorations, composite resin or ceramic materials can be utilized and the clinical results are considered to be admissible. When compared to ceramic inlay restorations, indirect composite resin inlay manufacturing is easier and less expensive. ${ }^{5}$ Alternatively, CAD/CAM technology is a well established method to process materials such as ceramics and composite resin. Such technologies aid in both designing, milling and finalizing the restorations in one appointment through the use of optimized composite resin, ceramic and combined materials. Various $\mathrm{CAD} / \mathrm{CAM}$ systems have proposed composite resin and ceramic blocks to product prosthetic restorations such as inlays, onlays, veneers and crowns. ${ }^{6}$
Adhesive luting system can influence long-term clinical performance of indirect restorations as well. Resin luting cements were classified in two groups in conformity with etching of the tooth surface before application: Etch-and-rinse, Self-etch. ${ }^{7}$ In addition to all these groups, self-adhesive cements were introduced a short time ago as a new subgroup of resin cements that exhibit some advantages like less technique sensitivity and clinical steps. Another classification is based on chemical components which include light-curing, self(chemical) curing and dual-curing systems. Dual-curing systems have been developed to combine some of the beneficial characteristics of self and light-curing cements. $^{8}$

Various agents have been utilized to determine the microleakge of restorations in in-vitro. Dyes, chemical tracers, radioactive isotopes, air pressure, bacteria, neutron activation analysis, scanning electron microscopy, artificial caries techniques, electrical conductivity and recently micro-CT have been used on dental tissue. ${ }^{9,10}$ Dye leakage is the most widely used method and low cost and easily manuplation are the primary benefits of this technique. ${ }^{9}$

Under consideration resarch, it has been found that satisfactory marginal adaptation between restoration and teeth is vital for the success of clinical rehabilitation. This study goals to assess the affect of various adhesive luting cements on the microleakage of proximal surfaces in class II indirect composite resin restorations. The null hypothesis was that the oclusal and gingival microleakge would be the same for all type of cements.

\section{MATERIALS AND METHODS}

\section{Tooth Selection and Preparation}

Twenty-four human caries-free third molars were chosen for this study. Tissue remnants were removed. Teeth were rinsed and immersed in distilled water at room temperature up to four months' prior use. This study was approved by the Ethics Committee of the Uşak University (146-09). The roots of the teeth were embedded in auto-polymerizing acrylic resin up to $2 \mathrm{~mm}$ apical to the cemento-enamel junction (Figure 1).
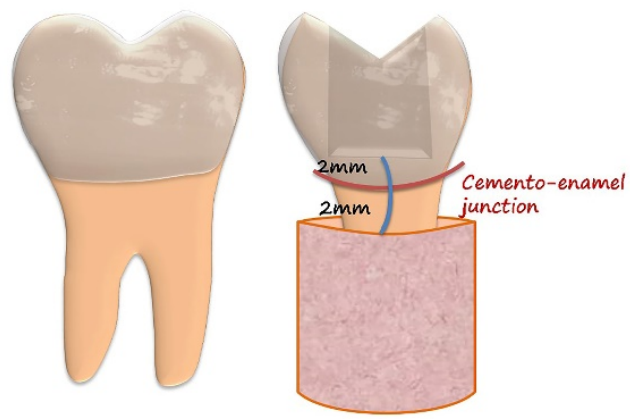

Figure 1: Schematic version of the preparation finishing margins applied in the study 


\section{Cavity Preparation}

Standard class II cavities were prepared free-hand using a chamfer type diamond bur (\#4130 KG Sorensen, São Paulo, Brazil) with known thickness with margins located above the cemento-enamel junction. Peparation dimensions were adjusted for each tooth to be buccolingual width was $4.0 \mathrm{~mm}$, mesio-distally width was $2.0 \mathrm{~mm}$ and occlusalgingival height was $4.00 \mathrm{~mm}$ and bur was renewed after 2 preparations (Figure 2). Throughout preparation, parallelometer was used to ensure standardization. After preperation, silicone impressions were obtained (Asia Chemi Teb Co; Tabriz, Iran, under the license of Coltene-Switzerland) and poured with type IV stone. The achieved stone casts were isolated with one coat of isolating liquid (Figure 3 ).
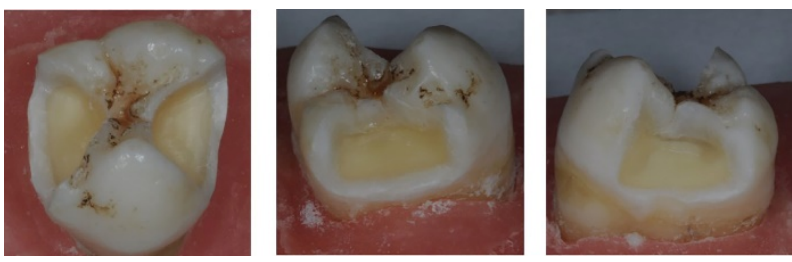

Figure 2: Standard class II cavities were prepared
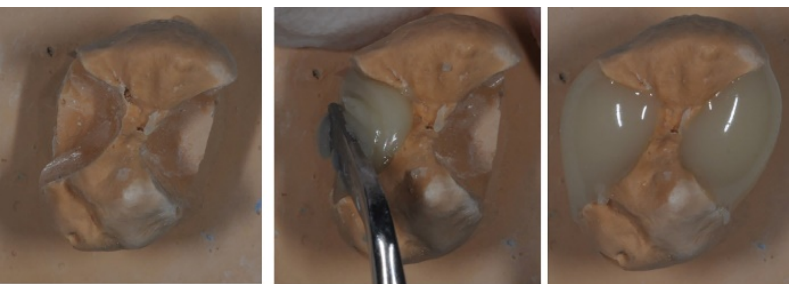

Figure 3: Indirect restorations manufactured over the cast which was obtained with type IV stone

\section{Inlay Fabrication}

Restorations were incrementally manufactured, with each layer 1-mm thickness, on stone cast model using indirect composite resin (DA1 shade; Gradia; GC, Japan) following manufacturer's instructions and each increment was light-polymerized (Bluephase G2, Ivoclar Vivadent, Schaan, Liechtenstein) with an energy output exceeding $600 \mathrm{mw} / \mathrm{cm}^{2}$ for 30s. All preparations were performed by the same operator (G.P.) to provide standardization. Final polymerization of the indirect restorations was performed with a laboratory type curing unit (GC Labolight LV-III) for 3 minutes following the manufacturer's instructions. Fifty $\mu \mathrm{m}$ aluminum oxide was used with airborne particle abrasion (pressure of 2.5 bar) during $10 \mathrm{~s}$ for treating inner surfaces of restorations. Then surfaces were etched with phosphoric acid 37\% (15s) and rinsed for $15 \mathrm{~s}$ and air dried. Before cementation, preparations were cleaned with pumice and water then air dried.

\section{Restorative Procedures}

The materials used in this study have been listed Table 1. Treatment groups were divided into 4 cements: GCem LinkAce (GCm) (GC, Japan), Panavia F 2.0 (P) (Kuraray, Japan), RelyX U200 (Rx) (3M ESPE, USA), Superbond C\&B (SB) (SunMedical, Japan) and control (V) (Variolink II, Ivoclar Vivadent, Schaan, Liechtenstein). In each tooth, the mesial cavity was set as the experimental and the distal as a control. Luting procedure and appropriate curing time was performed following each manufacturer's instructions (Figure 4) (Table 2).

Table 1.

\begin{tabular}{|l|l|l|l|l|}
\hline Materials & Codes & Manufacturer & Composition & Type \\
\hline Variolink II & $\mathrm{V}$ & $\begin{array}{l}\text { Ivoclar Vivadent, } \\
\text { Schaan, Liechtenstein }\end{array}$ & $\begin{array}{l}\text { Bisphenol a glycidyl methacrylate, urethane } \\
\text { dimethacrylate, triethylene glycol dimethacrylate, } \\
\text { silicon dioxide, } \\
\text { autopolymerizing initiators, light-polymerizing } \\
\text { initiators, stabilizer, pigments }\end{array}$ & Etch\& Rinse \\
\hline Panavia F & P & $\begin{array}{l}\text { Kuraray Co Ltd, } \\
\text { Osaka, Japan }\end{array}$ & $\begin{array}{l}\text { Bisphenol a glycidyl methacrylate, 10- } \\
\text { Methacryloyloxydecyl dihydrogen phosphate, quartz, } \\
\text { benzoyl peroxide, initiators, phosphate, monomer, } \\
\text { amine, sulfine, stabilizer }\end{array}$ & Dual-cure \\
\hline RelyX U 200 & Rx & $\begin{array}{l}\text { 3M ESPE; St Paul, } \\
\text { MN, USA }\end{array}$ & $\begin{array}{l}\text { Bisphenol a glycidyl methacrylate, triethylene glycol } \\
\text { dimethacrylate, silica-zirconia glass }\end{array}$ & Self-adhesive \\
\hline $\begin{array}{l}\text { Superbond } \\
\text { C\&B }\end{array}$ & SB & $\begin{array}{l}\text { Sun Medical, } \\
\text { Moriyama, } \\
\text { Japan }\end{array}$ & $\begin{array}{l}\text { 4-methacryloxyethyl trimellitate anhyderide as a } \\
\text { diffusion promoter and tri-n-butylborane as a } \\
\text { polymerization initiator. }\end{array}$ & Self-cure \\
\hline GCem & GCm & $\begin{array}{l}\text { GC, Tokyo, Japan } \\
\text { Urethane dimethacrylate, floro-alumino-silikat cam1, } \\
\text { dimetakrilat, fosforik asid ester monomer, silikon } \\
\text { dioksid, inisyator, inhibitor }\end{array}$ & Self-adhesive \\
\hline Gradia & & GC, Tokyo, Japan & $\begin{array}{l}\text { Micro-filled hybrid resin composite with microfine pre- } \\
\text { polymer resin fillers, a unique coupling agent and } \\
\text { urethane dimethacrylate co-monomer matrix }\end{array}$ & $\begin{array}{l}\text { Light-cure } \\
\text { composite }\end{array}$ \\
\hline
\end{tabular}


Table 2: Cements used in study and their clinical application

\begin{tabular}{|c|c|}
\hline Cement used in study & Clinic application \\
\hline Variolink II (V) & $\begin{array}{l}\text { Phosphoric acid gel was applied to the prepared tooth surface with a disposable brush for } 10-15 \\
\text { seconds, then rinsed and air dried. Subsequently, AdheSE Primer was performed for } 15 \mathrm{~s} \text { and then } \\
\text { air dried. All the prepared surfaces were coated with AdheSE Bond and polymerized for } 10 \text { seconds. } \\
\text { Variolink II was mixed in a 1:1 ratio on a mixing pad for } 10 \mathrm{~s} \text { and applied inner surface of the } \\
\text { restoration. }\end{array}$ \\
\hline GCem LinkAce (GCm) & $\begin{array}{l}\text { The mixing tip was attached firmly to the GC Automix Tip. Material was applied directly into the } \\
\text { restoration. }\end{array}$ \\
\hline Panavia F $2.0(\mathrm{P})$ & $\begin{array}{l}\text { Primer was performed to the internal surface of the restoration and dry. Equal amounts of paste A+ } \\
\mathrm{B} \text { was dispensed and mixed for } 20 \mathrm{~s} \text {. Mixing cement was applied to the inner surface of the } \\
\text { restoration. }\end{array}$ \\
\hline RelyX U200 (Rx) & Rely U200 was mixed on the mixing pad and applied to the inner surface of the restoration. \\
\hline Superbond C\&B (SB) & $\begin{array}{l}\text { Green activator was applied on dentin surface and rinsed Super-Bond C\&B monomer was performed } \\
\text { to the resin inner surface. Super-Bond C\&B was mixed using bulk-mix technique which polymer } \\
\text { powder ( } 4 \text { drops) and catalyst ( } 1 \text { drop) were mixed onto cooled dispensing dish and applied to the } \\
\text { inner surface of the restoration. }\end{array}$ \\
\hline
\end{tabular}

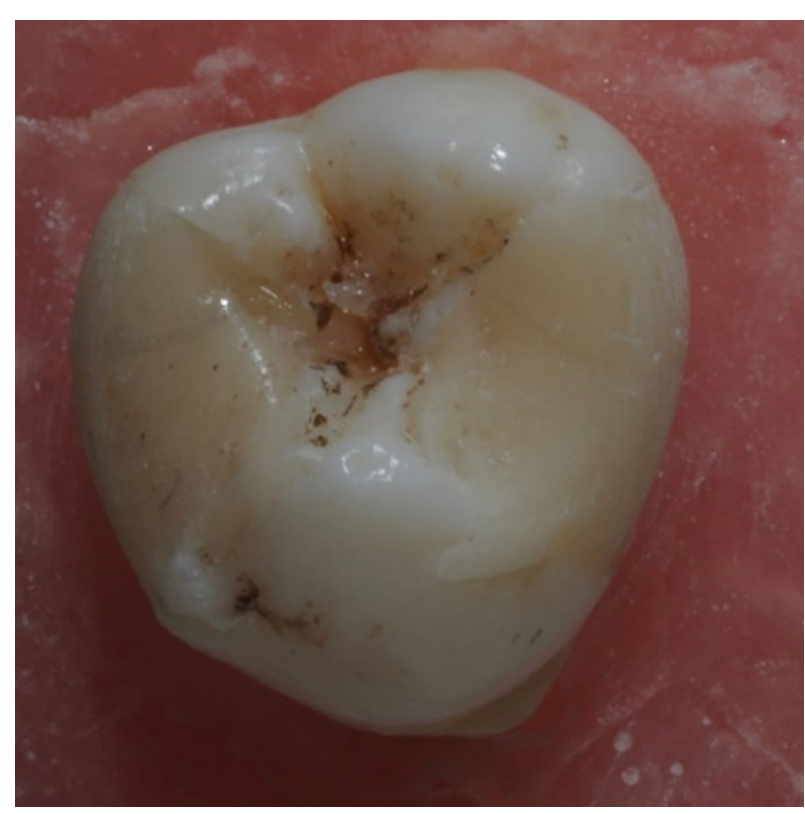

Figure 4: Luting was performed following each manufacturer's instructions.

\section{Microleakage Test}

After cementation, specimens were thermocycled (5$55 \mathrm{C}^{\circ}, 5000$ cycles) and immersed in $50 \%$ silver nitrate solution for 24 hours. The teeth were sectioned mesiodistally and the dye penetration pattern was assessed using a stereomicroscope $(24 x$; Leica optical microscope, Germany). The ordinal scale was used according to a previous study. The scoring system differed between no penetration to severe penetration $(0-4){ }^{11}$

$0=$ no dye penetration,

$1=$ dye penetration up to one-third of the cavity depth,

$2=$ dye penetration up to two-thirds of the cavity depth, $3=$ dye penetration up to the entire cavity depth, $4=$ dye penetration along axial Wall

\section{Statistical analysis}

Statistical analysis was performed using SPSS 18.0 for Windows software (Chicago, IL, USA). Mean values for each group were recorded and statistically analyzed using Wilcoxon Signed Ranks Test. P values less than 0.05 were considered to be statistically significant in all tests.

\section{RESULTS}

There were no significant differences among occlusal

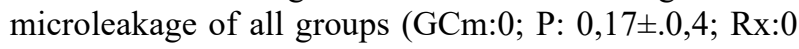
and $\mathrm{SB}: 0,17 \pm .0,4)(\mathrm{P}>0,05) \quad($ Graphic 1$)$. The least microleakage $(\mu \mathrm{m} \pm \mathrm{SD})$ was recorded for $\mathrm{GCm}$ and $\mathrm{Rx}$ self-adhesive cements for occlusal $(0.00 ; 0,00)$ and gingival $(0,83 \pm 0,4 ; 0,50 \pm 0,5)$ parts, respectively (Figure 5-6). The highest microleakage was noted with SB and $P$ at the gingival parts $(2,0 \pm 1,4 ; 1,5 \pm 0,84)$, respectively and the difference was significant compared to the other groups $(\mathrm{P}<0,05)$ (Figure 7-8) 


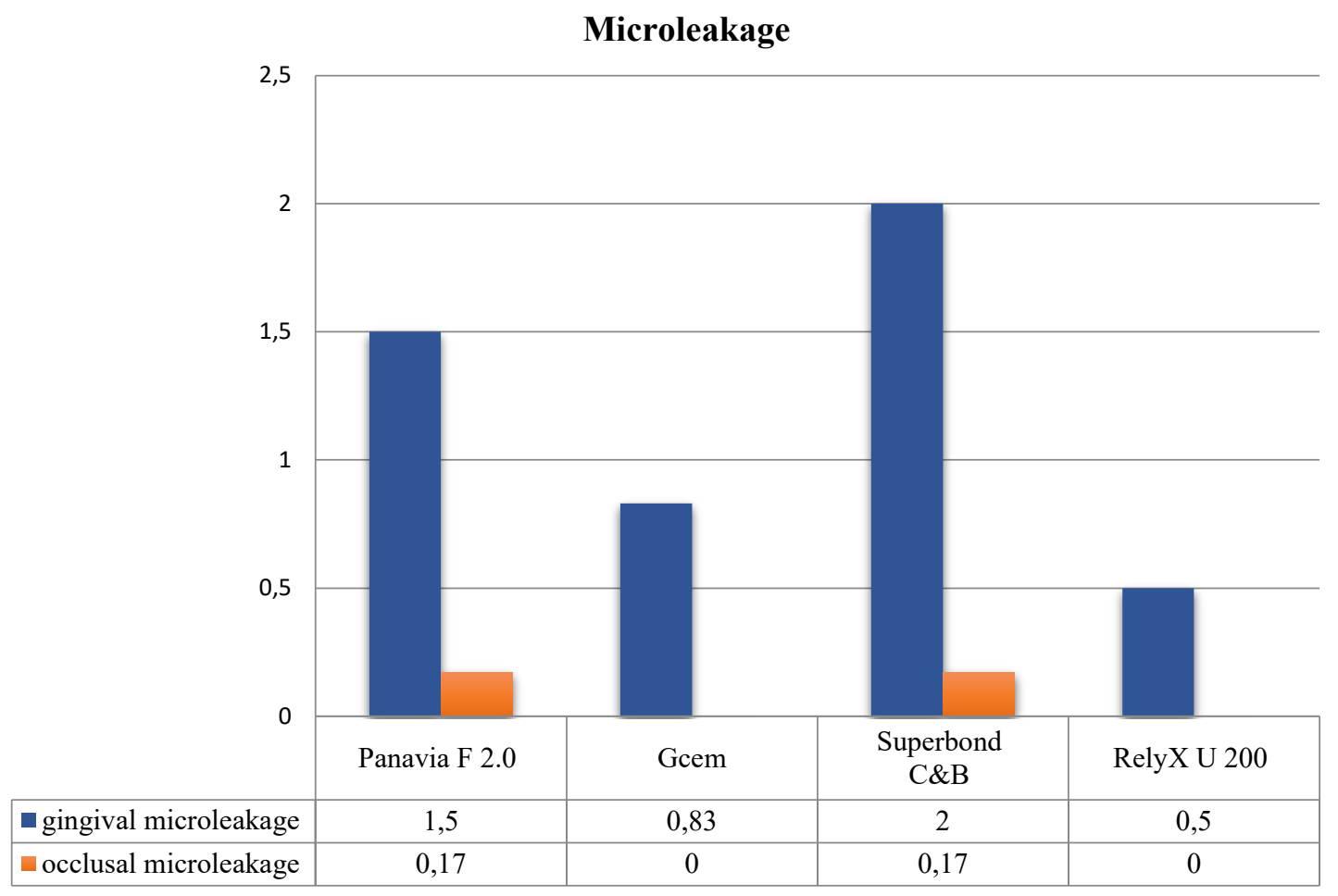

Graphic 1: Gingival and occlusal microleakage differences according to cements
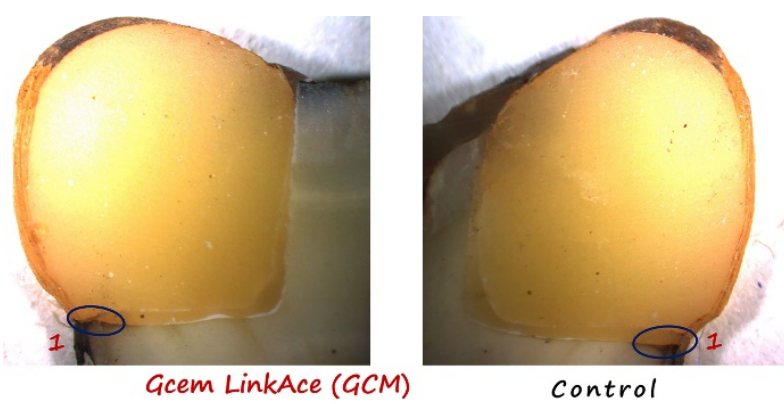

Figure 5: Digital image analysis for Gcem group exhibited that almost no dye penetration was observed when compared with the control group.

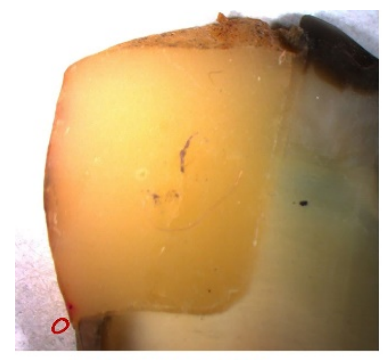

Relyx U $200(R x)$

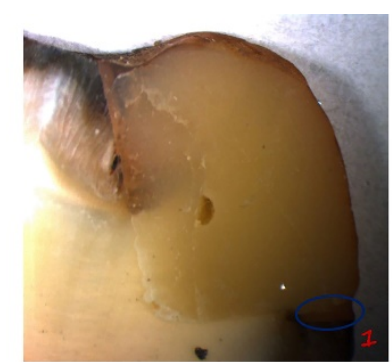

Control

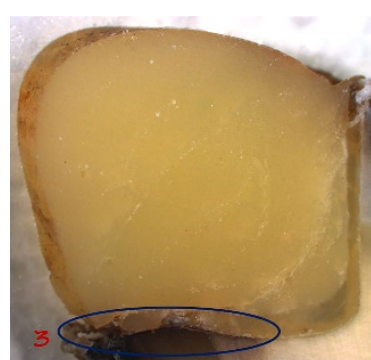

Superbond $C \& B(S B)$

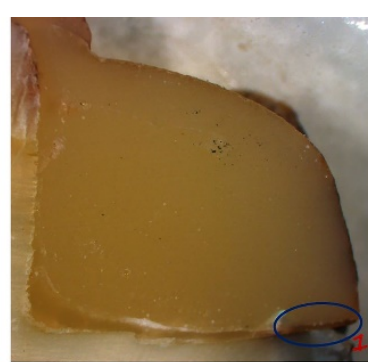

Control
Figure 7: For the self-curing resin group; marginal infiltration was classified with score 3 at cervical margin and in control group it was classified with score 1 .

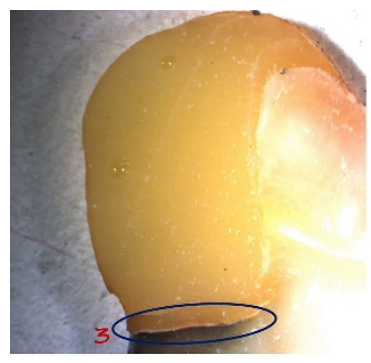

Panavia $F 2.0(P)$

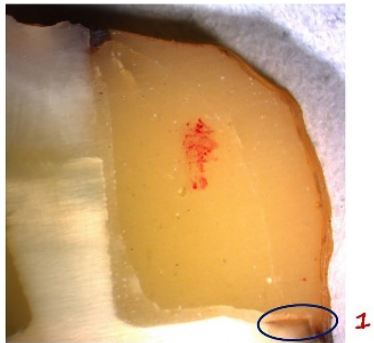

control
Figure 6: Digital image analysis revealed no penetration of the dye in RelyX treatment group when compared with the control group.
Figure 8: In Panavia group, marginal infiltration was classified with score 3 at cervical margin; whereas in control group it was classified with score 1 . 


\section{DISCUSSION}

The current study evaluated the microleakage of proximal surfaces in class II indirect composite resin restorations with different adhesives cements. According to the Wilcoxon signed rank test significantly lesser dye penetration score leakage was recorded for GCm and Rx groups at the gingival and occlusal parts. Besides this, the marginal adaptation is better than gingival adaptation for all treatment groups. Therefore, the null hypothesis was rejected.

In this study, satisfactory low microleakage values was recorded for GCm and Rx self-adhesive cements for both occlusal and gingival margins. The highest microleakage was noted with $\mathrm{SB}$ and $\mathrm{P}$ at the gingival parts. Other studies also suggested that Rely $\mathrm{X}$ resin cement yielded microleakage values almost as successful as the control group and Panavia shows higher microleakge values for occlusal and gingival margins than other self adhesive cements under ceramic and composite resin inlay restoraration. ${ }^{12,13}$

In this current study 2 different curing mode was investigated and self adhesive dual-curing resin cements exhibited lower microleakage whilst self-curing resin cement showed highest. It is expected that the dual curing will able to provide polymerization in deeper areas where light cannot reach with or without light. Unlike our results, Braga et al. concluded that the activation of dual cure cement with and without light effects contraction stresses and higher stress values were observed in the presence of light and also contraction stresess were releated with microleakage. ${ }^{14}$

The adaptation between tooth and restoration material at the gingival margin is considered critical in terms of microleakage than other sites. ${ }^{15}$ After the initiation of resin polymerization, two mechanism occur: shrinkage in the composite resin and inadequate adhesion to the adherent, simultaneously. ${ }^{16}$ Composite resin shrinkage is affected by many factors, such as cavity shape and size, the type of adherent, margin position, and sort of restorative and adhesive luting material utilized. In this study, adhesive luting material's effect on composite resin shrinkage was observed alone.

Marginal adaptation of restorative materials plays a vital role to obtain long-lasting restorations. Polymerization shrinkage can bring under control with indirect technique. Better marginal adaptation can be obtained when compared to direct application. ${ }^{1}$ In this study, the results of all the dentin margins were highly statistically significant results when compared to enamel margins and also the marginal gap in the gingival margin was higher than that in the occlusal margin in both resin cements. These distinctions may be elucidated due to the miscellaneous structural contents of dental tissues. Bonding to enamel is a method without detailed and primary technical needs or difficulties, whereas dentin bonding is much more complex due to its moist structure and excess organic content. ${ }^{4}$

The cavity preperation substantially affects the polymerization shrinkage. ${ }^{17}$ In our study, $4.0 \mathrm{~mm}$ buccolingual width, $2.0 \mathrm{~mm}$ was mesio-distally width and $4.00 \mathrm{~mm}$ occlusalgingival height cavity dimensions were carried out which were applied in accordance with other studies. ${ }^{18,19}$

Matrix systems are designed to achieve ideal anatomical proximal surfaces and contacts for composite resin materials. But in recent studies, it has been found that the use of the matrix and the type of matrix used do not significantly affect the quality and seal of composite resin restoration margins..$^{20,21}$ In our study, inlay restorations were prepared without matrix band.

In this study, we utilized the traditional section and stereomicroscope evaluation method. Although the Micro-CT method has been used for this purpose recently, Chen et al. evaluated microleakage with the micro-CT and stereomicroscope evaluation method and indicated that stereomicroscope achieved the best images. $^{22}$

A standard numerical chart was used and silver nitrate was utilized as the determination of gaps and leakage. With using digital image method, the depth of microleakage can be measured numerically after dye influence. Thus, more accurate results can be obtained. Before applying silver nitrate, a thermocycling protocol was utilized to mimic the mouth conditions because thermal changes can be raised microleakage almost at all margins. ${ }^{23}$ Some researchers have reported in their studies that the adequate marginal adaptation was achieved before the thermal cycle but not the same after administration. ${ }^{24,25}$

In this study, four different resin cements were compared with one type of indirect composite resin material and matrix band is not used during the manufacturing the restorations. Considering the limitations of this study, current cements, different evaluation methods and matrix band type effect can be evaluated in future studies.

\section{CONCLUSION}

Within the limitations of this study the following conclusion was made:

1. Tested self-adhesive dual-curing resin cements exhibited simulated long-term microleakage stability while self-curing resin cement yielded highest microleakage.

2. In comparison of occlusal and gingival margins in all resin groups, the marginal adaptation of gingival margin was the worst. 


\section{REFERENCES}

1. Ferreira MC, Vieira RS. Marginal leakage in direct and indirect composite resin restorations in primary teeth: an in vitro study. J Dent 2008;36(5):322-5.

2. Priyalakshmi S MR. A review on marginal deterioration of composite restoration. J Dent Med Sci 2014(13):6-9.

3. Pashley DH. Clinical considerations of microleakage. J Endod 1990;16(2):70-7.

4. Perdigão J. Dentin bonding as a function of dentin structure. Dent Clin North Am 2002;46(2):277-301.

5. Krejci I, Lutz F, Gautschi L. Wear and marginal adaptation of composite resin inlays. J Prosthet Dent 1994;72(3):233-44.

6. Beuer F, Schweiger J, Edelhoff D. Digital dentistry: an overview of recent developments for CAD/CAM generated restorations. Br Dent J 2008;204(9):50511.

7. Sezinando A. Looking for the ideal adhesive - A review. Revista Portuguesa de Estomatologia, Medicina Dentária e Cirurgia Maxilofacial. 2014;55(4):194-206.

8. Braga RR, Cesar PF, Gonzaga CC. Mechanical properties of resin cements with different activation modes. J Oral Rehabil 2002;29(3):257-62.

9. Going RE. Microleakage around dental restorations: a summarizing review. J Am Dent Assoc 1972;84(6):1349-57.

10. Swain MV, Xue J. State of the art of Micro-CT applications in dental research. Int $\mathrm{J}$ Oral Sci 2009;1(4):177-88.

11. Bedran de Castro AK, Pimenta LA, Amaral CM, et al. Evaluation of microleakage in cervical margins of various posterior restorative systems. J Esthet Restor Dent 2002;14(2):107-14.

12. Cal E, Celik EU, Turkun M. Microleakage of IPS empress 2 inlay restorations luted with self-adhesive resin cements. Oper Dent 2012;37(4):417-24.

13. Uludag B, Ozturk O, Ozturk AN. Microleakage of ceramic inlays luted with different resin cements and dentin adhesives. J Prosthet Dent 2009;102(4):23541 .
14. Braga RR, Ferracane JL, Condon JR. Polymerization contraction stress in dual-cure cements and its effect on interfacial integrity of bonded inlays. J Dent 2002;30(7-8):333-40.

15. Casagrande L, Brayner R, Barata JS, et al. Cervical microleakage in composite restorations of primary teeth--in vitro study. J Dent 2005;33(8):627-32.

16. Shih WY. Microleakage in different primary tooth restorations. J Chin Med Assoc 2016;79(4):228-34.

17. Han SH, Sadr A, Tagami J, et al. Internal adaptation of resin composites at two configurations: Influence of polymerization shrinkage and stress. Dent Mater 2016;32(9):1085-94.

18. Miletic V, Peric D, Milosevic M, et al. Local deformation fields and marginal integrity of sculptable bulk-fill, low-shrinkage and conventional composites. Dent Mater 2016;32(11):1441-51.

19. Roggendorf MJ, Krämer N, Appelt A, et al. Marginal quality of flowable 4-mm base vs. conventionally layered resin composite. J Dent 2011;39(10):643-7.

20. Sparks JD, Hilton TJ, Davis RD, et al. The influence of matrix use on microleakage in Class 5 glassionomer restorations. Oper Dent 1992;17(5):192-5.

21. Hofmann N, Hunecke A. Influence of curing methods and matrix type on the marginal seal of class II resinbased composite restorations in vitro. Oper Dent 2006;31(1):97-105.

22. Chen X, Cuijpers VM, Fan MW, et al. Validation of micro-CT against the section method regarding the assessment of marginal leakage of sealants. Aust Dent J 2012;57(2):196-9.

23. Gerdolle DA, Mortier E, Loos-Ayav C, et al. In vitro evaluation of microleakage of indirect composite inlays cemented with four luting agents. J Prosthet Dent 2005;93(6):563-70.

24. Campos EA, Ardu S, Lefever D, et al. Marginal adaptation of class II cavities restored with bulk-fill composites. J Dent 2014;42(5):575-81.

25. Agarwal RS, Hiremath $\mathrm{H}$, Agarwal $\mathrm{J}$, et al. Evaluation of cervical marginal and internal adaptation using newer bulk fill composites: An in vitro study. J Conserv Dent 2015;18(1):56-61. 